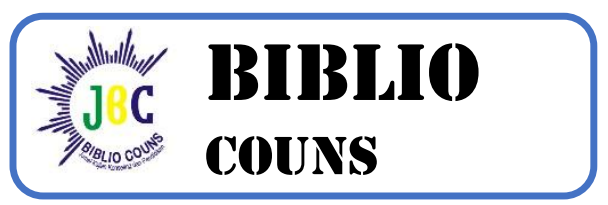

Biblio Couns : Jurnal Kajian Konseling dan Pendidikan

Vol. 1, No. 2, Juli 2018, hlm. 54-58

Tersedia Online di jurnal.umsu.ac.id/index.php/biblio

ISSN 2620-3103 (online)

DOI : https//doi.org/10.30596/bibliocouns.v1i2.2079

\title{
Miskonsepsi Program Studi BPI/BKI Fakultas Dakwah di PTKIN
}

\author{
Rizky Andana Pohan', Erfan Ramadhani ${ }^{2}$ \\ ${ }^{1}$ Program Studi Bimbingan Konseling Islam IAIN Langsa \\ andanapohan@iainlangsa.ac.id \\ ${ }^{2}$ Universitas PGRI Palembang \\ erfankonselor@gmail.com
}

\begin{abstract}
Abstrak
Miskonsepsi Prodi BPI/BKI merupakan salah satu hal yang sudah terjadi cukup lama. Miskonsepsi terhadap prodi ini dimulai dari pemerintah dalam hal ini Kementerian Agama, PTKIN meliputi seluruh civitas akademika prodi BPI/BKI, sampai kepada pengguna lulusan. Miskonsepsi ini harus segera diselesaikan oleh semua pemangku kebijakan dan civitas akademika untuk menyelamatkan kelangsungan masa depan prodi ini, dan tentunya adalah mahasiswa dan alumninya. Beberapa bentuk miskonsepsi prodi BPI/BKI Fakultas Dakwah yang dapat dianalisis mulai dari: (1) Penamaan Prodi, (2) Struktur Kurikulum, (3) Alumni bisa jadi konselor, (4) Rumpun Ilmu, (5) Objek Praktik Spesifik (OPS).
\end{abstract}

Kata Kunci : Miskonsepsi, BPI, BKI, PTKIN

\section{A. Pendahuluan}

Program studi (Prodi) Bimbingan Penyuluhan Islam/ Bimbingan Konseling Islam merupakan salah satu prodi yang ada di fakultas dakwah PTKIN di Indonesia. Prodi ini berdiri sudah begitu lama tetapi masih terasa belum jelas kemana arah output lulusan profesionalnya. Secara kurikulum hampir $60 \%$ struktur kurikulum adalah konseling sehingga mahasiswa beranggapan setelah tamat dapat menjadi seorang konselor yang profesional. Secara gelar akademik lulusannya adalah S.Sos, jika dirujuk kepada rumun ilmu Dikti dalam ilmu sosial prodi ini tidak termasuk didalamya. Itulah beberapa miskonsepsi dan kendala nyata yang harus di hadapi mahasiswa BPI/BKI juga berdampak pada kegalaun output lulusan, mau jadi apa setelah tamat.

\section{B. Pembahasan}


Miskonsepsi Prodi BPI/BKI merupakan kesalahpemahaman mengenai prodi BPI/BKI di PTKIN. Miskonsepsi ini harus segera diluruskan untuk memberikan kesamaan persepsi terhadap prodi BPI/BKI di Indonesia. Sehingga prodi ini dapat merumuskan dengan jelas keprofesionalan prodi ini dibandingkan dengan prodi lainnya. Prodi ini harus mempunyai Objek Praktik Spesifik yang jelas, yang dapat membedakan anatara prodi ini dengan prodi lainnya. Hal tersebut untuk menempatkan posisi yang jelas bagi para outputnya yaitu para alumninya. Jika miskonsepsi ini tidak segera dituntaskan maka prodi ini akan menjadi prodi yang galau dan merupakan salah satu prodi yang akan menyumbang pengangguran di era revolusi industri 4.0 ini. Beberapa miskonsepsi tersebut antara lain.

\section{Penamaan Prodi}

Untuk penamaan prodi seluruh PTKIN di Indonesia masih belum ada kata sepakat. Masih ada yang menamakan prodi BPI, ada juga yang berubah menjadi BKI? Yang manakah yang sebenarnya? Jika dirujuk pada sejarah prodi ini bermula pada penamaan prodi Bimbingan Penyuluhan Masyarakat (BPM), seiring berjalannya waktu berubah menjadi Bimbingan Penyuluhan Islam (BPI), selanjutnya keluarlah peraturan menteri agama yang menyatakan perubahan BPI ke BKI (Bimbingan dan Konseling Islam) Peraturan Menteri Agama (PMA) No. 36 tahun 2009. Selanjutnya berselang tujuh tahun kemudian keluarlah PMA No 33 Tahun 2016 BKI menjadi BPI. Namun hal ini rupanya ditanggapi beragam oleh berbagai PTKIN, ada yang masih tetap BKI (seperti UIN Imam Bonjol, UIN Sunan Kalijaga, UIN Ar Raniry dll) tetapi ada juga yang tetap pada prodi BKI (UIN Jakarta, UIN Sumatera Utara, IAIN Langsa, UIN Bandung, dll). Hal tersebut menjadi indikasi ketidakkonsistenan aturan yang dikeluarkan untuk kepentingan prodi ini. Jika dari sudut penamaan saja masih tidak ada kata sepakat, sudah pasti arah, tujuan, struktur kurilum, output juga beragam. Hal ini merupakan masalah yang sangat besar. Jika pemangku kepentingan tidak segera mengatasi ini, maka yang jadi korban sudah pasti adalah mahasiswanya yang akan terjun di dunia kerja.

\section{Struktur Kurikulum}

Kurikulum inti Prodi BPI/BKI di Indonesia adalah konseling. Hal tersebut harus diakui karena istiilah penyuluhan sudah tidak relevan untuk proses bantuan psikologis kepada manusia. Tentunya hal ini menimbulkan wacana dalam pikiran mahasiswa bahwa mereka bisa jadi konselor, bisa jadi guru BK. Secara nalar memang semua kurikulum prodi BK pada dipelajari yang tidak ada hanya ilmu pendidikan, berarti ada harapan bisa jadi konselor/guru BK, itulah asumsi mahasiswa prodi ini, dan tidak jarang ketika masa orientasi menjadi konselor sering terucap dari pemangku kepentingan prodi ini bisa menjadi konselor. Hal tersebut juga bisa dicek di setiap website pada prodi BPI/BKI Fakultas Dakwah PTKIN. 


\section{Alumni BPI/BKI Fakultas Dakwah PTKIN Bisa Jadi Konselor}

Profesional adalah kata kunci yang jelas untuk dapat menunjukkan eksistensi seseorang, begitu juga dengan program studi BPI/BKI harus dapat menciptakan profesi yang profesional. Berdasarkan Undang-Undang No 14 Tahun 2015 tentang guru dan dosen dijelaskan bahwa "Profesional adalah pekerjaan atau kegiatan yang dilakukan oleh seseorang dan menjadi sumber penghasilan kehidupan yang memerlukan keahlian, kemahiran, atau kecakapan yang memenuhi standard mutu atau norma tertentu serta memerlukan pendidikan profesi. Konselor merupakan salah satu profesi yang profesional, Permendiknas No 27 Tahun 2008 tentang standard kualifikasi akademik dan konpetensi konselor menjelaskan bahwa konselor mereka yang telah menamatkan S1 BK pendidikan plus pendidikan profesi konselor. Hal ini jelas menutup ruang prodi BPI/BKI Fakultas untuk dakwah untuk menjadi konselor maupun guru BK. Oleh sebab itu para pemangku prodi BPI/BKI ini harus segera merumuskan profesi yang tepat untuk alumninya. Hapuslah dari bayang-bayang penyebutan istilah konselor bagi mahasiswa, karena itu akan menjadi harapan yang hampa buat para alumninya.

\section{Rumpun Ilmu BPI/BKI Fakultas Dakwah}

Gelar terbaru alumni Prodi BPI/BKI adalah S.Sos. Hal ini berkonsekuensi bahwa para alumni beranggapan bahwa rumpun ilmunya adalah Ilmu Sosial. Sebagai contoh kasus, pada tahun 2017 dibukalah penerimaan CPNS besar-besaran oleh pemerintah pusat untuk kementerian/lembaga seluruh Indonesia. Beberapa formasi menerima S1 Sosial yaitu BKKBN (Penyuluh KB), BNN (Penyuluh Narkoba), Kemenkumham (Penyuluh Lembaga Pemasyarakatan). Secara keilmuan sesungguhnya para alumni BPI/BKI memang sesuai untuk mengisi lowongan ini, tetapi apalah daya, setelah di periksa di dalam rumpun ilmu Dikti, ternyata Prodi BPI/BKI tidak ada dalam rumpun ilmu sosial, hal tersebut sesuai dengan yang termaktub dalam surat Dirjen Belmawa Ditjen Dikti No. 2293/E3/2014 tanggal 28 Mei 2014 tentang Perubahan Nomenklatur Prodi yang mengacu pada rumpun ilmu KKNI dan penamaan secara internasional. Pupuslah harapan para alumni BPI/BKI dikarenakan keilmuannya tidak tercantum dalam rumpun ilmu Dikti secara Nasional, KKNI, dan Internasional. Hal berikutnya, yang menjadi pertanyaan, prodi BPI/BKI rumpun ilmunya mengacu kemana? Setelah ditelusuri ternyata berdasarkan PMA No 33 Tahun 2016 prodi ini masuk ke dalam rumpun ilmu dakwah. Rumpun ilmu dakwah inilah yang belum disosialisasikan secara maksimal, yang seharusnya rumpun ilmu ini harus disesuiakan dengan KKNI dan penamaan 
internasional. Inilah yang sangat menjadi masalah besar prodi ini yang sangat perlu diperhatikan untuk kejelasan masa depan alumninya kedepan.

\section{Objek Praktik Spesifik Prodi BPI/BKI Fakultas Dakwah PTKIN}

Tidak adanya komitmen bersama untuk melaksanakan PMA No 33 Tahun 2016, mengakibatkan tidak adanya kesamaan arah prodi ini ke depan. Hal ini berakibat pada pengakuan oleh masyarakat pengguna lulusan akan semakin kecil. Jika merujuk pada peraturan ini maka jelas bahwa untuk di Fakulktas Dakwah adalah prodi BPI. Namun mengapa masih ada PTKIN yang masih bersikukuh menjadi BKI dengan dalih bisa menjadi konselor padahal gelarnya adalah S.Sos. Hal inilah yang perlu dirumuskan dan disepakati kembali. Jika merujuk sejarah kementerian agama melahirkan jurusan ini untuk menciptakan penyuluh agama islam. Hal tersebut dapat diterima, kemudian yang menjadi keraguan berikutnya adalah mengapa ketika Kementerian Agama membuka penerimaan Penyuluh Agama Islam pada Tahun 2016 kualifikasi pendidikan yang diterima adalah seluruh alumni PTKIN Prodi manapun bisa mendaftar tanpa mempritaskan prodi ini? Mengapa tidak dikhususkan saja formasi ini untuk alumni prodi BPI? Hal inilah yang semakin membuat pertanyaan besar civitas akademika Prodi BPI/BKI Fakultas Dakwah terhadap komitmen Kemenag terhadap keprofesionalan prodi ini.

Mengapa tarik ulur ini terjadi, salah satu penyebabnya adalah BPI belum menemukan Objek Praktik Spesifik (OPS) yang jelas dalam keilmuannya. Full dalam Prayitno (2013) menjelaskan bahwa salah satu kriteria profesi adalah:

"Adanya OPS tersendiri bagi setiap jenis profesi, agar masing-masing konteks tugas tugas masing-masing profesi itu tidak saling tumpang tindih, sehingga diantara profesi dan kualifikasi profesi yang berbeda tidak saling mengaku satu objek yang sama sebagai wilayah kerja profesi atau kualifikasi profesi yang berbeda itu".

Jika Prodi BK OPS nya adalah pengembangan KES dan Penanganan KES-T (Prayitno, 2013). Pendidikan Guru Mata Pelajaran OPS nya adalah penguasaan materi pelajaran, dll. Maka prodi BPI sesungguhnya harus secepatnya menemukan OPS yang jelas untuk kelangsungan dan kemartabatan prodi ini ke depan.

\section{Penutup}

Miskonsepsi Prodi BPI/BKI Fakultas Dakwah PTKIN di Indonesia sudah menjarah ke seluruh lini civitas akademika. Mulai dari pihak prodi itu sendiri, dosen, mahasiswa, maupun pemerintah dalam hal ini kementerian agama, terlebih lagi pihak pengguna lulusan. Sesungguhnya Prodi ini adalah prodi yang sangat bermanfaat dan berkualitas, namun 
dikarenakan tidak adanya komitmen yang jelas dari semua pihak semakin membuat prodi ini melayang-layang tanpa arah yang jelas. Mahasiswa sebagai output lulusan akan menjadi korban. Pemerintah melalui Kementerian Agama dan PTKIN seharusnya sebagai produsen alumni harus segera menyelesaikan miskonsepsi ini, karena kalau dibiarkan berlarut-larut, maka dikhawatirkan pemerintah dalam hal ini Kementerian Agama akan di cap sebagai salah satu pencetak generasi yang tidak profesional di era Revolusi Industri 4.0.

\section{DAFTAR PUSTAKA}

Permendiknas No 27 Tahun 2008 tentang Standard Kualifikasi Akdemik dan Kompetensi Konselor.

Peraturan Menteri Agama No. 36 tahun 2009 tentang Pembidangan Ilmu dan Gelar Akademik di Lingkungan. Perguruan Tinggi Agama dan Keputusan Menteri Agama.

Peraturan Menteri Agama No 33 Tahun 2016 tentang Gelar Akademik Perguruan Tinggi Keagamaan.

Prayitno. 2013. Konseling Integritas. Padang: UNP Press.

Surat Dirjen Belmawa Ditjen Dikti No. 2293/E3/2014 tanggal 28 Mei 2014 tentang Perubahan Nomenklatur Prodi yang Mengacu pada Rumpun Ilmu, KKNI dan Penamaan Secara Internasional. 